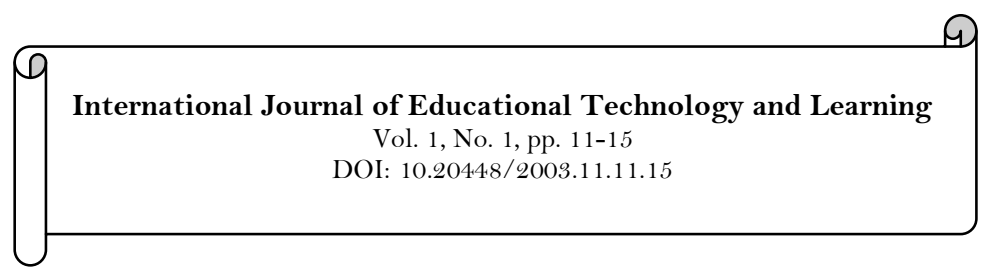

\title{
The Role of Guidance and Counselling in Effective Teaching and Learning in Schools: The Cameroonian Perspective
}

\author{
Einstein Moses Egebe Anyi ${ }^{1}$ \\ ${ }^{1}$ Associate Professor of Counselling Psychology, Head of Department, Science of Education and Guidance and Counselling, Higher \\ Technical Teacher Training College (HTTTC), Bambili, The University of Bamenda, The Republic of Cameroon
}

Abstract
The total development of a child can only take place in an
environment conducive for teaching and learning. It is in realization
of the above that all educational services which can promote teaching
and learning in schools are given prominent attention by educational
planners. Counselling services are among the school educational
services. It is believed that guidance and counselling services in
school shall develop, assess and improve educational programmes;
enhance teaching and improve the competence of the teacher and
reduce cost for the children. Therefore, this paper focused on the
need for effective counselling services in schools. Furthermore, the
paper examined the concept of counselling, the different counselling
services like educational, vocational and socio/personal, and
associated problems of guidance and counselling as they affect
teaching and learning in Camerons Attribution
recommended that individuals be made to understand, appreciate and
accept guidance and counselling services in schools because of the
roles they play in effective teaching and learning.

\section{Introduction}

Guidance and counselling is described as an enlightened process whereby people help people by facilitating growth and positive adjustment through self-understanding (Kolo, 2001). Akinade (2012) defines guidance and counselling as a process of helping an individual become fully aware of himself and the ways in which he is responding to the influences of his environment. It further assists him to establish some personal meaning for this behaviour and to develop and classify a set of goals and values for future behaviour. Corey, Corey, and Callanan (1988) regards counselling as a process which occurs in a one to one relationship between an individual troubled by problems with which he cannot cope with and a professional worker whose training and experiences have qualified him to help others reach solution to personal needs. Okoye (2010) viewed counselling as an interactional relationship designed to facilitate the personal development of information leading to effective decision making and awareness of the self.

Counselling is a learning process in which a counsellor helps an individual or individuals learn, understand themselves and their environment and be in a position to choose the right type of behaviours that will help them develop, grow, progress, ascend, mature and step up, educationally, vocationally and socio personally (Egbo, 2008). In other words, counselling is a transformative process of helping people to learn all that are to be learnt both in and outside the school.

Abolade (2000) describes teaching as a set of activities that are designed to bring about changes in the behaviour of learners. La'ah (2015) defines teaching as explaining, demonstrating, guiding and counselling by the teacher in order to effect a change in the learner. Okoye (2010) stated that "the main aim of teaching is to help someone acquire or change some skills, attitude, knowledge, idea or appreciation”. In other words, it is to bring about some desirable changes in the learners, she also noted that teaching is said to be effective only when the learners have been able to achieve the set behavioural objectives. Nnabuike (2012) believes that a teacher is also a learner because there is no end to learning.

Okoye (2010) views learning as the mental activity by which knowledge and skills, habits and attitudes, virtues and ideas are acquired, retained and utilized resulting in the progressive adoption and modification of conduct and behaviour. Thus, learning includes acquisition of knowledge, information, skills and cultures. He therefore noted that learning definitely will lead to change in one's thought, patterns and feeling. Learning 
involves cognitive process especially mental reasoning. Thus teaching and learning go together; it is like buying and selling. If nobody learns it follows that nobody teaches. Nnabuike (2012) noted that the work of the teacher is to help students to learn through deliberate and conscious manipulation of information, knowledge, skills, values, attitudes and habits of the learners in order to bring about learning, leading to desirable changes in character.

Based on the above, no effective teaching could be said to have taken place if learning has not occurred. In most schools in Cameroon, most teachers are cheating instead of teaching. Some do not know the methods for teaching and so do not make any positive impact (teaching and learning); some abandon the teaching job for which they are being paid, to engage in petty trading, farming and even contract. This is also affirmed by Odo (2007) who noted that majority of teachers do not conduct research to get more knowledge and for effective, efficient and qualitative teaching and for upgrading of knowledge and ideas. He noted that some teachers do not care about the students under their care. Kolo (2001) however, pointed out that teaching is a difficult task and therefore not every teaching brings about pupils learning. He noted that you can take a horse to the stream but you cannot force it to drink water. In a sense, it is possible that one could put in his best effort to teach and yet some pupils nay not learn. This is where counselling comes in for there are pupils who find it difficult to learn due to some learning problems. Some teachers do not understand why they are in school, what is expected of them and how to handle some of their problems. Guidance examines individual students based on the need of each student in understanding of his immediate environmental factors and the influences of such factors on the individual. It is designed to help each pupil adjust to his environment, develop the ability to set realistic goals for himself and to improve on his total educational programmes while in school and post school life.

\section{Objectives of Guidance and Counselling in Schools}

The objectives of guidance and counselling are not different from the objectives of education. The rationale behind counselling is that it is believed that individuals who understand themselves and their world will become transformed, productive, effective and happier human beings. Below are some of the major objectives of guidance and counselling in schools.

1) To develop in students an awareness of opportunities in the society through relevant and useful information.

2) To help students develop the skills of self-study, self-analysis and self-understanding.

3) To help students in making appropriate and satisfactory personal and educational choices.

4) To help student develop positive attitudes to self, to others, to work and to learning.

5) To help students acquire the skills of collecting and using information.

6) To help students who are underachieving use their potentials to the maximum.

7) To help children relate behaviour meaningfully to cognitive achievement and the chances of success in life.

8) To help student acquire as early as possible in their lives a positive image of self through selfunderstanding and self-direction.

9) To assist students in the process of developing and acquiring skills in problem solving and decision making.

10) To help build up/or sharpen the child's perception of reality, development of a sense of autonomy and to whip up the motivation for creativity and productivity.

11) To work with significant others in the life of the child, helping them to understand the needs and problems of the child with the purpose of creating, arousing and sustaining their interest in and their understanding of the child's needs, problems and goals so that the child could be optimally helped to attain those goals, handle those problems and meet those needs.

12) To help route the nations human resources into appropriate useful and beneficial channels thus preventing unnecessary economic bottlenecks.

13) To help identify and nurture human potentialities in various fields of study endeavours, thus ensuring adequate manpower in the various sectors of the nation's economy.

14) To help build up in individual Cameroonians positive attitudes to fellow Cameroonians and a sense of commitment to the unity of Cameroon.

15) To help the child as early as possible to learn to appreciate Cameroonian cultural values.

\section{Major Counselling Services in Schools}

According to Egbo (2008) the rationale for guidance and counselling in schools is based on the belief that prevention is always better than cure in every aspect of life. She therefore noted that counselling no doubt has the key for the prevention of almost all the problems associated with learning, therefore the need to understand the services provided under the school guidance programme towards attainment of effective teaching and learning. These counselling services include; 
1. Orientation service: This is designed to assist students adjust adaptively when found in new school environment for effective learning. The teachers should also be given orientation on how to handle the learners from time to time.

2. Information service: This service is designed to provide students with data about educational, social and vocational opportunities. It involves collection of data for students.

3. Appraisal service: Appraisal involves the collection, administration, interpretation and clinical usage of variety of test devices in order to provide effective counselling services to students.

4. Placement service: The goal of this service is to ensure that students achieve placement whether on programme of the study, a career, work study or even a medical treatment programme.

5. Follow-up, research or evaluation service: The goal of this service is to provide feedback on the effectiveness of school guidance through research into the concrete outcomes of the school guidance.

6. Referral service: This is sending a client to another person or agency for assistance where the counsellor is unable to solve the problem. The counsellor does not claim to know everything and so the need for referral to other needs of the

7. Counselling service: Counselling service is the interaction between a client and counsellor that aims at solving or understanding the client's problems the more. He also stated that this interaction enhances effective teaching and learning.

8. Teachers' forum: The Teachers Forum is meant to gather all the teachers in the school to discuss teacher/students problems (Teaching and Learning). The counsellor uses this programme to introduce himself to the teachers and what he stands to do in the school. The counsellor invites some resource persons who will talk to teachers on some students need areas that affect teaching and learning, like harmony in the place of work, cordial relationship between teachers and students, handling students without stress, different methods of teaching, learner's individual differences and so on.

Guidance and counselling services when rendered as should be rendered in the schools bearing in mind the national goals of education will no doubt go a long way in ensuring effective teaching and learning in schools.

\section{Problems Facing Guidance and Counselling in Schools}

Odu (2004) stated that the main aim of guidance and counselling is to assist the student to develop physically, mentally, emotionally, morally and educationally to cope with the learning situations within and outside the school environment. Some of these services provided by counsellors are hindered because of the following problems;

1. Lack of trained counsellors: Despite the fact that there are many holders of higher degrees in guidance and counselling in Cameroon today, not as many are qualified to be real counsellors because they lack the skills necessary for the practice. There is limited number of trained counsellors in Cameroonian schools and the ones already trained choose to go into non-school settings (Akinade, 2012).

2. Doubt about the efficacy of guidance and counselling: Some people such as uninitiated colleagues, teachers, principals or administrators doubt the efficacy of counselling. They are sceptical about reliance on its use (Akinade, 2002).

3. Lack of Commitment of Government officers: More committed action will help the growth of the profession.

4. Lack of or inadequate funding: Guidance and counselling is not well funded today in Cameroon, the education enterprise has become a costly venture. Enough funds are not allocated to each school to run its various services. Where funds are available, very little is earmarked for counselling purposes. It seems the various levels of government do not want to stretch their budgets with extra demands from emerging units such as guidance and counselling, yet it is known that effective counselling demands adequate funding to purchase items such as psychological tests, journals and various publications, play gadgets, cardboards and various felt pens as well as money to organize activities such as Orientation, Excursions, Career Clubs and Career Day/Week and furnishing counsellors' offices.

5. Confidentiality: Clients expect that their secrets or privileged information be kept secret or confidential and not exposed to others. However, referral agents such as teachers, peers, parents, principals etc. expect counsellors to divulge such information to them. Failure of the counsellor to reveal the "secret" may raise the degree of suspicion of his activities. Revealing the secrets lead to loss of faith in counselling and counsellors on one part will lose clients. Yet all these are happening (Akinade, 2012).

6. Counsellors created problems: Counsellors also create major problems to guidance and counselling delivery. Some are not fully committed to the counselling profession. Instead of being serious minded in their counselling duties, some join in the staff room discussions.

7. Feeling of suspicion of the role/or integrity of counsellors: Some school personnel still see the counsellor as having a "hidden agenda" or something to hide when a client goes into the counselling room (where this is available); some give counsellors negative or derogatory labels. This is more so where the other workers doubt the moral integrity of counsellors who give individual counselling to young ones. This 
feeling becomes more serious when a male counsellor treats female students and gives the interaction high confidentiality (Olandejo, 2006).

8. Blurred role of the guidance counsellor: Several people in the society do not know the specific roles of the counsellor. Even in the school settings, where awareness is expected to be high, school personnel such as teachers and principals do not understand or they misconstrue the functions of the counsellors. For instance, Makinde (1980) wrote that head teachers see them as rivals instead of helpers.

\section{Conclusion}

Guidance and counselling is of paramount importance in effective teaching and learning in school in Cameroon and globally. It is transformer, reformer in educational, vocational and socio-personal practices in every society. UNESCO 2002 has recognized the pivotal role which guidance and counselling plays in various spheres of human existence, hence it sponsored the development of training modules for counsellors. Counselling is aimed at helping an individual become aware of himself and his environment and therefore be in a position to choose the right type of behaviour, educational, vocational and socio personal in nature. Therefore guidance and counselling no doubt has a lot of roles to play for effective teaching and learning and therefore deserves maximum support of everybody.

\section{Recommendations}

The following recommendations are made for promoting effective teaching and learning in schools through the recognition of what counsellors do.

1) There is need for serious enlightenment on the part of the public to accept guidance and counselling. This will help develop strategies for school administrators and teachers to achieve a realistic perception of students in their school environment.

2) Government should support guidance and counselling practically by providing and making funds available for all the services in guidance and counselling.

3) Guidance and counselling should be made an integral part of the school programme and therefore supported by all concerned.

4) The guidance counsellor should be consulted by the school administration in implementing some of the counselling programme.

5) Guidance counsellors on their own part in the school be committed to the counselling programmes through helping the teachers with the identification of students with learning problems and inform the teachers, so that different individualized methods can be used for effective teaching and learning.

6) Government should help to train and appoint qualified guidance counsellors in schools to help meet with the students' problems.

7) Parents also should be included in guidance and counselling programme through giving them progressive reports of their children.

8) Counsellors should understand their limits in helping the students and therefore make use of referrals.

9) Counsellors should keep students' secrets with utmost confidentiality.

10) There is need for the clarity about the services rendered by school counsellors. This is done by defining the counsellors' roles, functions and objectives for the benefit of school administrators, teachers, students, parents, staff and community.

\section{References}

Abolade, A. O. (2000). Having knowledge of teaching skills a must for teacher. The Nigerian Journal of Guidance and Counselling, 7(1), 93-94.

Akinade, E. A. (2002). Concise counselling practicum: A basic text for colleges and universities. Ibadan: Olu Akin Publishers.

Akinade, E. A. (2012). Introduction to modern guidance and counselling. Ibadan: Brightway Publishers.

Corey, G., Corey, M. S., \& Callanan, P. (1988). Issues and ethics in the helping professions. Pacific Grove, CA: Brooks Cole.

Egbo, A. C. (2008). Organisation of guidance and counselling in schools. Enugu: Joe Best Publishers.

Kolo, F. D. (2001). Elements of psychological testing for counsellors and psychologists. Zaria: Amadu Bello Co.

La'ah, D. (2015). An evaluation of teachers utilization in Zaria secondary schools: Implication for guidance and counseling. Academic Research International, 6(5).

Makinde, O. (1980). A survey of counselling approaches.

Nnabuike, E. K. (2012). Practical guide to effective teaching. Enugu: Hallmark Publishers.

Odo, E. (2007). Factors inhibiting teacher's effectiveness. Journal of Educational Psychology, 3(4), 110-1 19.

Odu, B. K. (2004). Counselling intervention and crisis management as medium of improving psychological well-being of the students. Journal of Educational Research and Evaluation, 4(1), 140-148.

Okoye, A. U. (2010). Counselling in the industrial setting vis-a-vis industrial relation. Aroko: Erudiete Publishers.

Olandejo, O. (2006). Guidance and counselling. A functional approach. Lagos: John Lad Publishers ltd. 


\section{Bibliography}

Makinde, O. (1987). Fundamentals of guidance and counselling. London: Macmillan Publishers.

Martin, A. (2012). Responding and reflective skills: The counsellor guide. Available from www.thecounsellorguide.co.uk.

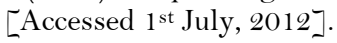

Ogunyemi, B. (2003). The counsellor and other school personnel: Practical collaboration for quality education. The Counsellor, 19(2): 27-42.

Okoh, S.E. (2006).Guidance for the 6-3-3-4 system of education. Zaria: Zaria Institute of Education Press, Amadu Bello University.

Salawu, A.A. (2000).Introduction to guidance and counselling reading in education(vol. 1). Sokoto: Educational Foundation Unit, Usman Dan Fodio University, Sokoto.

Egbo, A. C. (2013). Development of guidance and counselling. Enugu: Agada Publishers.

Egbo, A. C. (2013). The role of guidiance and counselling in effective teaching and learning in schools: The Nigerian perspective. A Paper Presented at the European Conference on Education 2013. 